\title{
Distribution of sterane maturity parameters in a lacustrine basin and their control factors: A case study from the Dongying Sag, East China
}

\author{
Chen Zhonghong*, Zha Ming, Jin Qiang and Ren Yongjun \\ College of Geo-Resources and Information, China University of Petroleum, Qingdao, Shandong 266555, China \\ (C) China University of Petroleum (Beijing) and Springer-Verlag Berlin Heidelberg 2011
}

\begin{abstract}
Fifty samples from the source rocks in Member 3 and Member 4 of the Paleogene Shahejie Formation in the Bohai Bay Basin, East China, were analyzed to investigate the distribution, evolution of the molecular maturity ratios $\mathrm{C}_{29} \beta \beta /(\beta \beta+\alpha \alpha)$ and $\mathrm{C}_{29} 20 \mathrm{~S} /(20 \mathrm{~S}+20 \mathrm{R})$ and their control factors in the natural geological profile and sequence. The results showed that progressive changes in molecular maturity parameters are associated with major changes in thermal evolution of related biomarkers. Increases in the $\mathrm{C}_{29} \beta \beta /(\beta \beta+\alpha \alpha)$ and $\mathrm{C}_{29} 20 \mathrm{~S} /(20 \mathrm{~S}+20 \mathrm{R})$ ratios result from the difference in the relative rate between generation and thermal degradation of isomers involved. The samples from a hyper-saline environment below $3.5 \mathrm{~km}$ in which evaporitic rocks deposited shows high response of $\mathrm{Sr} / \mathrm{Ba}, \mathrm{Sr} / \mathrm{Ca}, \mathrm{Fe} /$ $\mathrm{Mn}, \mathrm{Pr} / \mathrm{n}-\mathrm{C}_{17}, \mathrm{Ph} / \mathrm{n}-\mathrm{C}_{18}$ and gammacerane and low response of $\mathrm{Pr} / \mathrm{Ph}$. There presents negative reversal of biomarker maturity $\mathrm{C}_{29} \beta \beta /(\beta \beta+\alpha \alpha), \mathrm{C}_{29} 20 \mathrm{~S} /(20 \mathrm{~S}+20 \mathrm{R})$ and $\mathrm{Ts} /(\mathrm{Ts}+\mathrm{Tm})$ in the samples from hypersaline environment, reflecting that the gypsum- halite have negative effect on the isomerization of biomarker and thermal evolution of organic matter. The minerals in evaporites also retard the conventional thermal indicators including vitrinite reflectance $\left(R_{\mathrm{o}}\right)$ and pyrolysis peak temperature $T_{\max }$ at the depth below 3.4 $\mathrm{km}$ (i.e. $>3.4 \mathrm{~km}$ ), and these parameters also show the inhibition from overpressure in the range of 2.4-3.4 $\mathrm{km}$. This result will be helpful in the interpretation and application of molecular maturity parameters for similar saline lacustrine basins.
\end{abstract}

Key words: $\mathrm{C}_{29}$ 24-ethyl cholestane, biomarker, thermal maturity parameters, saline basins, Dongying Sag

\section{Introduction}

Quantitative study of biomarker transformation and trend in the distribution of biomarker maturity ratios with increasing burial depth are rarely found in literature. The reason is mainly the lack of suitable set of samples. However, this kind of study is essential for understanding related biomarkers and the distribution of biomarker maturity ratios, which are widely used in petroleum exploration.

In this study, four types of $\mathrm{C}_{29}$ 24-ethyl cholestanes isomers were detected: $5 \alpha, 14 a, 17 \mathrm{a}-\mathrm{C}_{29}$ cholestane (20S), is referred to as $\mathrm{C}_{29} \mathrm{~S} \alpha \alpha ; 5 \alpha, 14 \beta, 17 \beta-\mathrm{C}_{29}$ cholestane (20S), is referred to as $\mathrm{C}_{29} \mathrm{~S} \beta \beta ; 5 \alpha, 14 \alpha, 17 \alpha-\mathrm{C}_{29}$ cholestane (20R), is referred to as $\mathrm{C}_{29} \mathrm{R} \alpha \alpha$; and $5 \alpha, 14 \beta, 17 \beta-\mathrm{C}_{29}$ cholestane (20R), is referred to as $\mathrm{C}_{29} \mathrm{R} \beta \beta$.

The $\mathrm{C}_{29} 20 \mathrm{~S} /(20 \mathrm{~S}+20 \mathrm{R})$ ratio is based on the relative enrichment of the $20 \mathrm{~S}$ isomer compared with the biologicallyinherited 20R isomer to reach an equilibrium end-point of 0.50-0.55 (Mackenzie and Mckenzie, 1983). Preferential

*Corresponding author. email: hongczh@163.com Received November 16, 2010 generation of the $20 \mathrm{~S}$ isomer and preferential loss of the $20 \mathrm{R}$ isomer are identified as the dominant controls on this $\mathrm{C}_{29} 20 \mathrm{~S} /$ (20S+20R) ratio (Dzou et al, 1995; Requejo, 1994). Other factors such as rock matrix (or organic matter) effects are used to explain the difference in the $20 \mathrm{~S}$ content between coals and shales with equivalent geothermal histories (Strachan et al, 1989).

The parameters $\mathrm{C}_{29} 20 \mathrm{~S} /(20 \mathrm{~S}+20 \mathrm{R})$ and $\mathrm{C}_{29} \beta \beta /(\beta \beta+\alpha \alpha)$ have been widely used in petroleum geochemistry as indicators of thermal maturity. Profiles of these ratios versus depth are widely used for describing the thermal maturity of source rocks or oils (Seifert and Moldowan, 1986). These ratios are mainly used in oil/gas evolution beyond the oil window (Farrimond et al, 1998), although they are known to give anomalous values dependent upon organic facies (Rullk tter and Marzi,1988), which is perhaps related to specific precursors (ten Haven et al, 1986).

Biomarker maturity parameters generally increase with increasing burial depth before they reach an equilibrium value. However, a number of molecular maturity parameters exhibit a significant maturity reduction or "reversal" after they reach equilibrium, such as the two parameters $\mathrm{C}_{29} 20 \mathrm{~S}$ / 
$(20 \mathrm{~S}+20 \mathrm{R})$ and $\mathrm{C}_{29} \beta \beta /(\beta \beta+\alpha \alpha)$ for $\mathrm{C}_{29}$ 24-ethyl cholestane, the thermal reversal of which has been recorded both in the laboratory and also in sedimentary basins (Mackenzie et al, 1980; ten Haven et al, 1986; Peters et al, 1990; Strachan, et al, 1989; Chen, 1997; Wang et al, 2006).

Most of previous investigations of biomarker maturity parameters have been conducted in the laboratory, including hydrous pyrolysis experiments or other types of pyrolysis experiment in closed system. However, laboratory experiments may not simulate the actual burial-related maturation which is controlled by a wide range of geological factors (Lewis, 1993). Quantitative studies of biomarker ratio evolution using data from natural depositional sequences are rare (Requejo, 1994; Farrimond et al, 1998).

Requejo (1994) investigated nine samples, which have uniform lithologies and organic facies, from the Upper Devonian Duvernay Formation (Western Canada Basin), covering a maturity range from immature to overmature with respect to hydrocarbon generation. He found that different maturity parameters are controlled at different extents by isomerization progress and by the relative rate between the generation and thermal degradation of isomers. Farrimond et al (1998) quantitatively studied biomarkers from the Tertiary section (1,400-3,000 m) of a well located in the Barents Sea, and analysed 27 samples covering a maturity range from immature to mature with respect to hydrocarbon generation. The results showed the importance of the relative rate between generation and thermal degradation of isomers, and suggested that increased concentration of individual isomer was the result of biomarker generation from kerogen and other macromolecular/polar fractions.

Further investigations are necessary. We studied the maturity ratios $\mathrm{C}_{29} 20 \mathrm{~S} /(20 \mathrm{~S}+20 \mathrm{R})$ and $\mathrm{C}_{29} \beta \beta /(\beta \beta+\alpha \alpha)$ in Paleogene lacustrine source rocks in the Dongying sag, a lacustrine rift basin in East China. The sources rocks are present in Members 4 and 3 of the Shahejie Formation (Zhu et al, 2004; Chen et al, 2004), and are comprised of dark mudstones and some evaporites over 1,000 m thick. These source rocks have been previously investigated by our lab team (Chen et al, 2004, 2005, 2008, 2009; Chen and Zha, 2006, 2007, 2008). Samples came from wells Feng-8, Fengshen-1, Shi-121 and Shi-126 over a depth range of 2,800 $\mathrm{m}$ to $4,000 \mathrm{~m}$ and cover most of the oil window.

\section{Regional geological setting}

The Dongying sag is a typical rift basin located in the southern Bohai Bay Basin, covering an area of about 5,700 $\mathrm{km}^{2}$. The Paleogene succession is dominated by mudstone with interbedded carbonates, gypsum-evaporite rocks and sandstones. The main source rocks comprise the upper part of Member $4\left(E s_{4}\right)$ and lower part of Member $3\left(\mathrm{Es}_{3}\right)$ of the Shahejie Formation.

During early Es4 deposition, chemical sediments began to be deposited in response to the hot and dry climatic conditions. Some 400-600 m of grey mudstones with evaporite and gypsum intervals were deposited in the centre of the lacustrine basin (Zhu et al, 2003; Chen et al, 2009). Tectonic subsidence then increased significantly and a largescale rift basin formed (Zhu et al, 2004) under a hot and dry climate. Large volumes of water evaporated with a resulting increase in salinity. Evaporites and mudstones thus dominate the middle part of the $\mathrm{E} s_{4}$ member (Fig. 1). The overlying Member 3 of the Shahejie Formation $\left(\mathrm{E} s_{3}\right)$ is dominated by

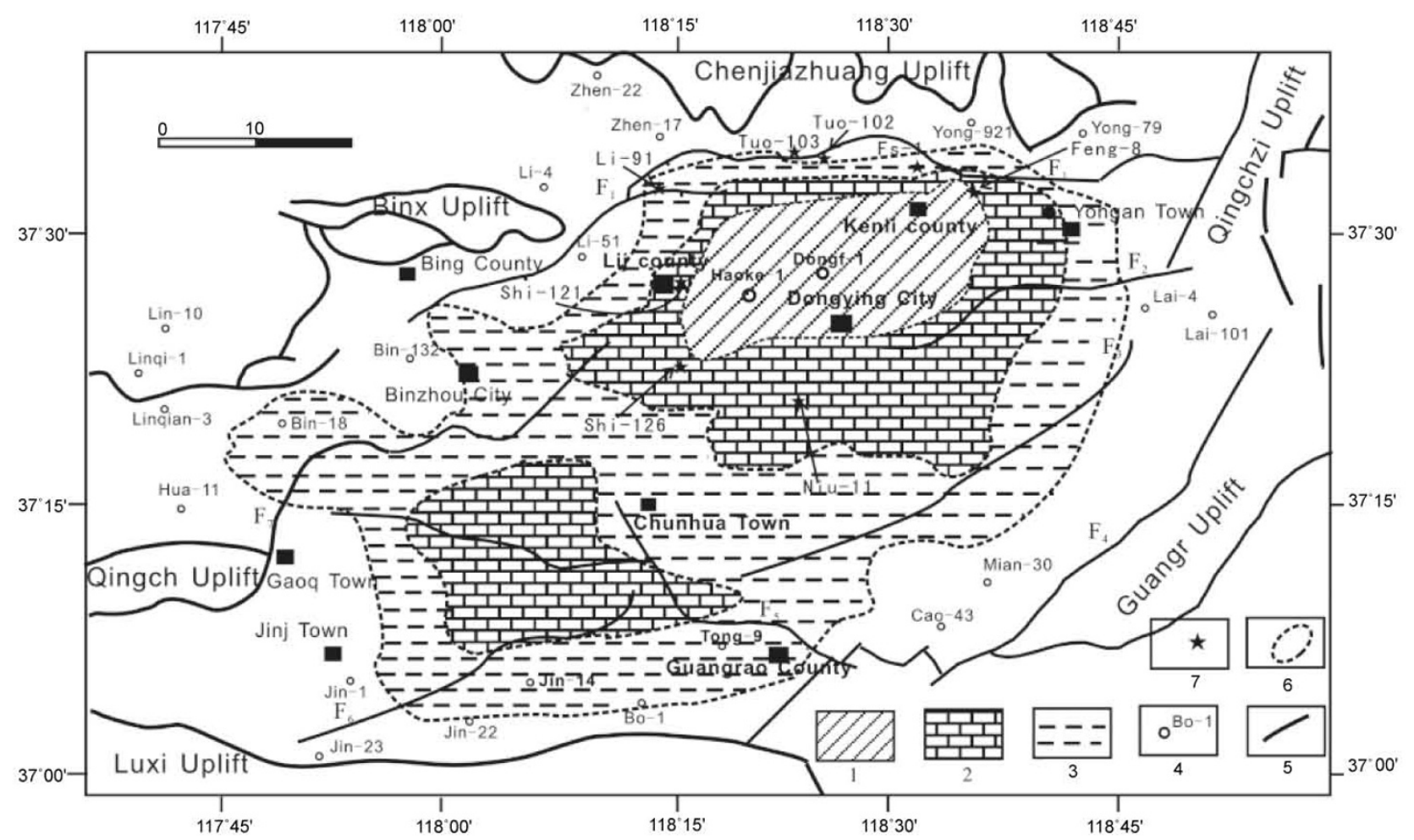

Fig. 1 Distribution of the co-sedimentary system of evaporites and source rocks in the middle part of Member 4 of the Shahejie Formation in the Dongying Sag 1. halite, gypsum; 2. limestone, dolomite; 3 . mudstone; 4 . wells; 5 . faults; 6 . boundary of different sedimentary systems; 7 . the wells for the samples coring 
dark mudstones with some oil shales and thin sandstones.

The dark mudstones and evaporites in the upper to middle parts of $\mathrm{Es}_{4}$ and the middle to lower parts of $\mathrm{Es}_{3}$ constitute the main source rock intervals in the depression (Chen et al, 2004; Chen and Zha, 2006). Theoretical investigations and exploration data show that the threshold of oil generation occurs at around 2,800 $\mathrm{m}$ (Chen et al, 2005).

\section{Experimental methods}

We analyzed 50 source rock samples (Table 1) from the Dongying Sag in Bohai Bay Basin, East China. The rock samples were cored from $\mathrm{E} s_{3}$ and $\mathrm{E} s_{4}$ of the Paleogene Shahejie Formation in the Wells Feng-8, Fs-1, Shi-121, Shi126, Niu-11, Li-91, Tuo-102 and Tuo-103. These wells are located around the Lijin sub-sag which is recognized as the main oil source in Dongying Sag (Fig. 1). The middle part of the $\mathrm{E} s_{4}$ member around Lijin sub-sag is dominated by evaporites and mudstones. The $\mathrm{Es}_{3}$ samples are dark mud and dark-gray mud, and the $\mathrm{Es}_{4}$ samples are dark mud, dark-gray mud, and gypsum-mud.

Table 1 The relative contents of molecular biomarkers (\%) and their ratios

\begin{tabular}{|c|c|c|c|c|c|c|c|c|c|c|c|c|c|c|}
\hline Well & Depth, m & Strata & $\mathrm{S} \alpha \alpha$ & $\mathrm{R} \beta \beta$ & $\mathrm{S} \beta \beta$ & $\mathrm{R} \alpha \alpha$ & Ts & $\mathrm{Tm}$ & $\mathrm{H}_{30}(17 \mathrm{a})$ & $\mathrm{R}_{30}$ & $\begin{array}{c}\mathrm{Ts} / \\
(\mathrm{Ts}+\mathrm{Tm})\end{array}$ & $\begin{array}{c}\mathrm{C}_{29} 20 \mathrm{~S} / \\
(20 \mathrm{~S}+20 \mathrm{R})\end{array}$ & $\begin{array}{c}\mathrm{C}_{29} \beta \beta / \\
(\beta \beta+\alpha \alpha)\end{array}$ & $\mathrm{R}_{30} / \mathrm{H}_{30}$ \\
\hline FS-1 & 2870 & $\mathrm{E} s_{3}$ & 3.22 & 7.35 & 1.17 & 19.90 & 2.21 & 3.53 & 27.11 & 1.90 & 0.38 & 0.14 & 0.27 & 0.070 \\
\hline Niu-11 & 3318 & $\mathrm{Es}_{3}$ & 7.11 & 6.50 & 4.76 & 9.89 & 3.19 & 2.21 & 27.30 & 1.25 & 0.59 & 0.42 & 0.40 & 0.046 \\
\hline Shi-121 & 3289.6 & $\mathrm{E} s_{3}$ & 7.16 & 5.62 & 4.01 & 9.29 & 3.68 & 2.66 & 26.32 & 2.77 & 0.58 & 0.43 & 0.37 & 0.105 \\
\hline Shi-121 & 3521.8 & $\mathrm{E} s_{3}$ & 2.92 & 7.27 & 5.91 & 4.25 & 4.10 & 1.66 & 27.91 & 1.38 & 0.71 & 0.43 & 0.65 & 0.049 \\
\hline Shi-121 & 3561.9 & $\mathrm{E} s_{3}$ & 3.80 & 7.12 & 6.74 & 4.58 & 4.31 & 2.03 & 25.30 & 1.26 & 0.68 & 0.47 & 0.62 & 0.050 \\
\hline Shi-121 & 3563 & $\mathrm{E} s_{3}$ & 4.22 & 7.50 & 7.01 & 4.68 & 4.26 & 2.08 & 25.58 & 1.12 & 0.67 & 0.48 & 0.62 & 0.044 \\
\hline Shi-121 & 3563.5 & $\mathrm{E} s_{3}$ & 2.74 & 8.53 & 6.81 & 4.00 & 5.87 & 1.23 & 27.83 & 1.13 & 0.83 & 0.43 & 0.69 & 0.041 \\
\hline Shi-121 & 3565.9 & $\mathrm{E} s_{3}$ & 3.86 & 6.40 & 6.13 & 4.72 & 4.54 & 1.59 & 28.66 & 1.49 & 0.74 & 0.47 & 0.59 & 0.052 \\
\hline Shi-121 & 3568.5 & $\mathrm{Es}_{3}$ & 3.35 & 7.72 & 5.66 & 4.08 & 4.88 & 1.58 & 29.24 & 1.09 & 0.76 & 0.43 & 0.64 & 0.037 \\
\hline Shi-121 & 3569.25 & $\mathrm{E} s_{3}$ & 3.22 & 8.31 & 6.17 & 3.84 & 6.64 & 1.26 & 27.17 & 1.57 & 0.84 & 0.44 & 0.67 & 0.058 \\
\hline Shi-121 & 3572.8 & $\mathrm{E} s_{3}$ & 2.78 & 8.04 & 5.50 & 3.61 & 5.58 & 1.36 & 27.99 & 1.36 & 0.80 & 0.42 & 0.68 & 0.048 \\
\hline Shi-121 & 3575.8 & $\mathrm{E} s_{3}$ & 4.07 & 9.35 & 6.88 & 5.37 & 5.04 & 1.80 & 28.16 & 1.11 & 0.74 & 0.43 & 0.63 & 0.040 \\
\hline Shi-121 & 3577.2 & $\mathrm{E} s_{3}$ & 3.85 & 7.62 & 6.63 & 4.69 & 5.50 & 1.34 & 27.23 & 1.29 & 0.80 & 0.46 & 0.63 & 0.047 \\
\hline Shi-121 & 3578.5 & $\mathrm{Es}_{3}$ & 3.88 & 9.25 & 6.87 & 4.97 & 3.85 & 1.77 & 26.25 & 1.31 & 0.69 & 0.43 & 0.65 & 0.050 \\
\hline Shi-121 & 3580.8 & $\mathrm{E} s_{3}$ & 4.02 & 11.08 & 7.23 & 5.39 & 4.39 & 2.00 & 25.94 & 1.35 & 0.69 & 0.41 & 0.66 & 0.052 \\
\hline Shi-121 & 3582.1 & $\mathrm{E} s_{3}$ & 4.03 & 11.26 & 7.44 & 5.13 & 4.14 & 1.84 & 25.92 & 1.40 & 0.69 & 0.41 & 0.67 & 0.054 \\
\hline Shi-121 & 3582.7 & $\mathrm{E} s_{3}$ & 3.92 & 9.56 & 6.73 & 4.60 & 4.54 & 1.75 & 25.90 & 1.37 & 0.72 & 0.43 & 0.66 & 0.053 \\
\hline Shi-121 & 3585 & $\mathrm{E} s_{3}$ & 3.90 & 10.84 & 6.77 & 4.73 & 4.73 & 1.91 & 26.57 & 1.24 & 0.71 & 0.41 & 0.67 & 0.047 \\
\hline Shi-126 & 3521.9 & $\mathrm{Es}_{3}$ & 5.73 & 13.72 & 6.35 & 6.91 & 3.42 & 2.35 & 29.16 & 1.14 & 0.59 & 0.37 & 0.61 & 0.039 \\
\hline Shi-126 & 3525.6 & $\mathrm{E} s_{3}$ & 4.38 & 7.72 & 7.07 & 5.18 & 4.07 & 1.68 & 25.22 & 1.45 & 0.71 & 0.47 & 0.61 & 0.057 \\
\hline Tuo-103 & 2806 & $\mathrm{E} s_{3}$ & 3.60 & 5.87 & 1.40 & 20.80 & 1.47 & 2.53 & 41.55 & 1.92 & 0.37 & 0.16 & 0.23 & 0.046 \\
\hline Tuo-104 & 2963.7 & $\mathrm{E} s_{3}$ & 3.85 & 5.34 & 0.92 & 13.12 & 1.96 & 3.72 & 26.86 & 2.24 & 0.34 & 0.21 & 0.27 & 0.083 \\
\hline Tuo-104 & 2966.2 & $\mathrm{E} s_{3}$ & 6.98 & 5.54 & 3.11 & 11.69 & 1.68 & 3.20 & 28.15 & 1.76 & 0.34 & 0.37 & 0.32 & 0.062 \\
\hline Tuo-104 & 3185.5 & $\mathrm{E} s_{3}$ & 4.25 & 5.18 & 3.08 & 10.21 & 2.41 & 3.03 & 25.00 & 1.25 & 0.44 & 0.32 & 0.36 & 0.050 \\
\hline Tuo-104 & 3432.4 & $\mathrm{E} s_{3}$ & 5.22 & 4.61 & 2.94 & 5.31 & 3.44 & 3.57 & 23.03 & 3.88 & 0.49 & 0.45 & 0.42 & 0.168 \\
\hline Fan-1 & 3311.7 & $\mathrm{E} s_{4}$ & 7.86 & 16.18 & 8.94 & 7.88 & 6.97 & 3.78 & 23.31 & 2.51 & 0.65 & 0.41 & 0.61 & 0.108 \\
\hline Feng-8 & 3050 & $\mathrm{E} s_{4}$ & 6.75 & 7.59 & 2.11 & 17.70 & 1.84 & 3.55 & 26.22 & 1.71 & 0.34 & 0.26 & 0.28 & 0.065 \\
\hline Feng-8 & 3164 & $\mathrm{E} s_{4}$ & 10.49 & 7.71 & 4.23 & 16.76 & 1.80 & 3.01 & 25.38 & 0.95 & 0.37 & 0.38 & 0.30 & 0.038 \\
\hline Feng-8 & 3166 & $\mathrm{E} s_{4}$ & 10.82 & 7.73 & 4.51 & 15.78 & 2.07 & 3.40 & 24.92 & 1.10 & 0.38 & 0.39 & 0.32 & 0.044 \\
\hline Feng-8 & 3403 & $\mathrm{E} s_{4}$ & 11.09 & 10.36 & 8.46 & 11.79 & 2.08 & 2.85 & 27.15 & 4.26 & 0.42 & 0.47 & 0.45 & 0.157 \\
\hline Feng-8 & 3403.4 & $\mathrm{E} s_{4}$ & 9.89 & 8.32 & 7.44 & 11.61 & 1.89 & 2.44 & 28.26 & 3.99 & 0.44 & 0.47 & 0.42 & 0.141 \\
\hline
\end{tabular}




\begin{tabular}{|c|c|c|c|c|c|c|c|c|c|c|c|c|c|c|}
\hline Well & Depth, m & Strata & $\mathrm{S} \alpha \alpha$ & $\mathrm{R} \beta \beta$ & $\mathrm{S} \beta \beta$ & $\mathrm{R} \alpha \alpha$ & Ts & $\mathrm{Tm}$ & $\mathrm{H}_{30}(17 \mathrm{a})$ & $\mathrm{R}_{30}$ & $\begin{array}{c}\mathrm{Ts} / \\
(\mathrm{Ts}+\mathrm{Tm})\end{array}$ & $\begin{array}{c}\mathrm{C}_{29} 20 \mathrm{~S} / \\
(20 \mathrm{~S}+20 \mathrm{R})\end{array}$ & $\begin{array}{c}\mathrm{C}_{29} \beta \beta / \\
(\beta \beta+\alpha \alpha)\end{array}$ & $\mathrm{R}_{30} / \mathrm{H}_{30}$ \\
\hline Feng-8 & 3816.3 & $\mathrm{E} s_{4}$ & 4.71 & 9.77 & 6.99 & 5.94 & 5.26 & 3.01 & 10.86 & 14.12 & 0.64 & 0.43 & 0.61 & 1.300 \\
\hline Feng-8 & 3818 & $\mathrm{E} s_{4}$ & 5.41 & 10.73 & 7.47 & 6.59 & 4.50 & 2.57 & 14.67 & 10.45 & 0.64 & 0.43 & 0.60 & 0.712 \\
\hline Feng-8 & 3947 & $\mathrm{E} s_{4}$ & 2.65 & 6.04 & 4.13 & 3.58 & 6.07 & 1.27 & 24.16 & 2.53 & 0.83 & 0.41 & 0.62 & 0.105 \\
\hline Fs-1 & 3440 & $\mathrm{E} s_{4}$ & 9.11 & 10.97 & 8.60 & 10.21 & 2.12 & 2.53 & 27.75 & 5.28 & 0.46 & 0.46 & 0.50 & 0.190 \\
\hline Fs-1 & 3685.6 & $\mathrm{E} s_{4}$ & 9.92 & 10.66 & 8.33 & 9.56 & 5.44 & 2.53 & 26.28 & 4.56 & 0.68 & 0.47 & 0.49 & 0.173 \\
\hline Fs-1 & 3686.3 & $\mathrm{E} s_{4}$ & 9.39 & 11.17 & 8.15 & 10.27 & 5.15 & 2.55 & 25.58 & 4.61 & 0.67 & 0.45 & 0.50 & 0.180 \\
\hline $\begin{array}{c}\mathrm{G} \text { u a } \mathrm{n}- \\
118\end{array}$ & 3000 & $\mathrm{E} s_{4}$ & 9.04 & 7.18 & 4.60 & 12.57 & 0.83 & 2.05 & 25.34 & 4.11 & 0.29 & 0.41 & 0.35 & 0.162 \\
\hline Li-91 & 3030 & $\mathrm{E} s_{4}$ & 6.35 & 8.25 & 5.08 & 7.08 & 2.37 & 2.80 & 29.28 & 2.24 & 0.46 & 0.43 & 0.50 & 0.076 \\
\hline Tuo-102 & 3467.8 & $\mathrm{E} s_{4}$ & 5.51 & 5.01 & 4.60 & 5.26 & 1.98 & 3.11 & 27.18 & 2.33 & 0.39 & 0.50 & 0.47 & 0.086 \\
\hline Tuo-102 & 3565 & $\mathrm{E} s_{4}$ & 4.01 & 5.12 & 5.35 & 5.01 & 4.06 & 2.00 & 28.69 & 1.80 & 0.67 & 0.48 & 0.54 & 0.063 \\
\hline Tuo-102 & 3656.7 & $\mathrm{E} s_{4}$ & 4.92 & 4.82 & 4.88 & 3.72 & 3.37 & 2.25 & 22.68 & 1.76 & 0.60 & 0.53 & 0.53 & 0.078 \\
\hline Tuo-103 & 3339.7 & $\mathrm{E} s_{4}$ & 3.06 & 6.38 & 3.45 & 4.72 & 3.35 & 2.69 & 27.54 & 1.47 & 0.56 & 0.37 & 0.56 & 0.053 \\
\hline Tuo-103 & 2993.4 & $\mathrm{E} s_{4}$ & 4.90 & 4.97 & 2.72 & 12.01 & 1.98 & 2.91 & 30.70 & 1.31 & 0.40 & 0.31 & 0.31 & 0.043 \\
\hline Tuo-103 & 3108.4 & $\mathrm{E} s_{4}$ & 4.32 & 6.33 & 2.65 & 8.80 & 2.19 & 3.21 & 24.10 & 1.51 & 0.41 & 0.32 & 0.41 & 0.063 \\
\hline Tuo-103 & 3169.8 & $\mathrm{E} s_{4}$ & 5.74 & 4.73 & 3.79 & 8.02 & 2.81 & 2.17 & 33.20 & 1.27 & 0.56 & 0.43 & 0.38 & 0.038 \\
\hline Tuo-104 & 3431.4 & $\mathrm{E} s_{4}$ & 6.70 & 4.08 & 3.82 & 5.16 & 2.26 & 2.73 & 27.38 & 1.72 & 0.45 & 0.53 & 0.40 & 0.063 \\
\hline Tuo-104 & 3533.2 & $\mathrm{Es} s_{4}$ & 3.37 & 5.80 & 2.25 & 3.15 & 3.64 & 2.71 & 22.98 & 0.98 & 0.57 & 0.39 & 0.55 & 0.043 \\
\hline Tuo-104 & 3537.6 & $\mathrm{Es}_{4}$ & 4.26 & 2.86 & 3.46 & 3.71 & 2.73 & 2.91 & 26.85 & 2.57 & 0.48 & 0.54 & 0.44 & 0.096 \\
\hline Wang-46 & 3788 & $\mathrm{E} s_{4}$ & 5.77 & 7.48 & 3.16 & 12.05 & 1.65 & 2.83 & 23.16 & 6.34 & 0.37 & 0.31 & 0.37 & 0.274 \\
\hline
\end{tabular}

Notes: $\mathrm{S} \alpha \alpha, \mathrm{R} \beta \beta, \mathrm{S} \beta \beta, \mathrm{R} \alpha \alpha$ are $\alpha \alpha \alpha \mathrm{C}_{29}(20 \mathrm{~S}), \alpha \beta \beta \mathrm{C}_{29}(20 \mathrm{R}), \alpha \beta \beta \mathrm{C}_{29}(20 \mathrm{~S}), \alpha \alpha \alpha \mathrm{C}_{29}(20 \mathrm{R})$ respectively, and their relative contents are the ratios of their concentrations compared to the total concentrations in the $\mathrm{m} / \mathrm{z} 217$; Ts, Tm, $\mathrm{H}_{30}(17 \mathrm{a})$ and $\mathrm{R}_{30}$ are $18 \alpha-\mathrm{C}_{27} \mathrm{Hopane}, 17 \alpha-\mathrm{C}_{27} \mathrm{Hopane}, 17 \alpha-21 \beta$ $\mathrm{C}_{30}$ Hopane and gammacerane respectively, and their relative contents are the ratios of their concentrations compared to the total concentrations in the $\mathrm{m} / \mathrm{z} 191$.

Chloroform was used as solvent for 72 hours of continuous extraction at a constant temperature of $70{ }^{\circ} \mathrm{C}$ in a Soxhlet apparatus and then evaporated to dryness. $10-15 \mathrm{mg}$ of extractant was dissolved by adding petroleum ether, then repeatedly washed and moved in a flask, standing for $24 \mathrm{~h}$ (about $100 \mathrm{~mL}$ of petroleum ether in flask), and then filtered. The insoluble part was asphaltene; the soluble part was a mixture of saturated hydrocarbons, aromatic hydrocarbons and non-hydrocarbons.

A silica-alumina column was prepared. The alumina was activated for $5 \mathrm{~h}$ at $450^{\circ} \mathrm{C}$, and the silica was activated for 8 $\mathrm{h}$ at $150{ }^{\circ} \mathrm{C}$. The silica and alumina was filled into the column at a silica/alumina ratio of $3: 1$ in volume with silica above alumina. After wetting the column with petroleum ether, a sample of the filtrate was poured into the column. Washing with petroleum ether, dichloromethane and diethyl ether, separately, we obtained saturated hydrocarbons, aromatic hydrocarbons and non-hydrocarbons, respectively.

An HP-Chemistation GC-MS analyzer was used (Model HP-5890 II for the GC, HP-5890A for the MS; Column: DB5MS; Column length: $60 \mathrm{~m}$; internal diameter: $0.25 \mathrm{~mm}$ ). The temperature was elevated from an initial $100{ }^{\circ} \mathrm{C}$ to the final $320^{\circ} \mathrm{C}$ at a heating rate of $4.0^{\circ} \mathrm{C} / \mathrm{min}$. The temperature of the gasification and transmission line was $310^{\circ} \mathrm{C}$, the ion source temperature $250{ }^{\circ} \mathrm{C}$, and the pre-column pressure was 170 $\mathrm{kPa}$. The split ratio was 20:1, and the carrier gas was helium. Electron energy was $70 \mathrm{eV}$, the scan rate was $0.46 \mathrm{can} / \mathrm{s}$, with electron-impact ionization.

Biomarkers were identified by using the mass fragmentogram and relative retention time in comparison with standard sample. Quantification of biomarker was performed by peak area response in specific mass chromatograms $(\mathrm{m} / \mathrm{z}$ 191 and $\mathrm{m} / \mathrm{z}$ 217). For some samples from $\mathrm{Es}_{4}$ member, the relative contents of $\mathrm{C}_{29}$ 24-ethyl cholestane isomers were calculated from the mass chromatogram combined with the mass spectrogram to eliminate or reduce the effect of coprostane.

Thirty samples (Table 2) were separately crushed in a rotary mill, and their aliquots were submitted to RockEval pyrolysis for determination of total organic carbon (TOC) content, residual soluble hydrocarbon $\left(S_{1}\right)$, pyrolysed hydrocarbon $\left(S_{2}\right)$, production index $(\mathrm{PI})$ (The production index (PI) is the ratio of already generated hydrocarbon to potential hydrocarbon), hydrogen index $\left(I_{\mathrm{H}}\right)$, temperature of maximum kerogen pyrolysate yield $\left(T_{\max }\right)$ and so on. Vitrinite reflectance $\left(R_{\mathrm{o}}\right)$ analyses were performed on randomly 
oriented grains using conventional microphotometric methods. The instruments were calibrated with known standard.

The contents of inorganic elements were measured by inductively coupled plasma-atomic emission spectroscopy (ICP-AES) and atomic absorption spectroscopy (AAS) in the well drilling.

\section{Results and discussion}

\subsection{Distribution of the molecular parameters from 2.8-3.57 km}

At a depth of $2.8-3.57 \mathrm{~km}$, the environment of the formation was a fresh to brackish depositional system. The distribution of the biomarkers maturity parameters $\mathrm{C}_{29} 20 \mathrm{~S} /$ $(20 \mathrm{~S}+20 \mathrm{R})$ and $\mathrm{C}_{29} \beta \beta /(\beta \beta+\alpha \alpha)$ reflects the process of the molecular parameters with thermal maturation.

Results indicate that in the depth range of $2.8-3.57 \mathrm{~km}$, the relative contents of the $\mathrm{C}_{29}$ isomers, $\mathrm{C}_{29} \mathrm{~S} \alpha \alpha$ and $\mathrm{C}_{29} \mathrm{~S} \beta \beta$, increase with increasing thermal evolution. At around 3.57 $\mathrm{km}$, these two isomers appear to reach equilibrium, and then exhibit a decrease trend. By contrast, the isomers $\mathrm{C}_{29} \mathrm{R} \alpha \alpha$,
$\mathrm{C}_{29} \mathrm{R} \beta \beta$ decrease in relative content with increasing thermal evolution before equilibrium, and their trends then change in the opposite direction (Fig. 2). The $\mathrm{C}_{29} 20 \mathrm{~S}$ cholestane isomers thus in general follow the same evolution path. For the $\mathrm{C}_{29} 20 \mathrm{R}$ isomers, $\mathrm{C}_{29} \mathrm{R} \beta \beta$ shows smaller changes with increasing depth than $\mathrm{C}_{29} \mathrm{R} \alpha \alpha$. Before reaching thermal equilibrium, the relative contents of the total $\beta \beta(S \beta \beta+R \beta \beta)$ and total S-type $(\mathrm{S} \alpha \alpha+\mathrm{S} \beta \beta)$ increase with thermal evolution, while the relative contents of the total $\alpha \alpha(\mathrm{S} \alpha \alpha+\mathrm{R} \alpha \alpha)$ and total R-type $(\mathrm{R} \alpha \alpha+\mathrm{R} \beta \beta)$ decline with thermal evolution. After thermal equilibrium, all the isomers show the opposite evolutionary trends to their original profiles.

For Member 3 and Member 4, the biomarkers maturity parameters $\mathrm{C}_{29} 20 \mathrm{~S} /(20 \mathrm{~S}+20 \mathrm{R})$ and $\mathrm{C}_{29} \beta \beta /(\beta \beta+\alpha \alpha)$ are consistent in terms of their overall distribution. Ratios increase with increasing burial depth in the interval 2.8-3.57 $\mathrm{km}$ before equilibrium; After thermal equilibrium, ratios then decline with further increase in burial depth (Fig. 3). The study result shows that the equilibrium value of $\mathrm{C}_{29} 20 \mathrm{~S} /$ $(20 \mathrm{~S}+20 \mathrm{R})$ ratio for $\mathrm{Es}_{3}$ and $\mathrm{E} s_{4}$ is 0.5 and 0.55 respectively, and the equilibrium value of $\mathrm{C}_{29} \beta \beta /(\beta \beta+\alpha \alpha)$ ratio for the two sequences is 0.7 and 0.6 respectively. This is mostly consistent with the results reported by Seifert and Moldowan

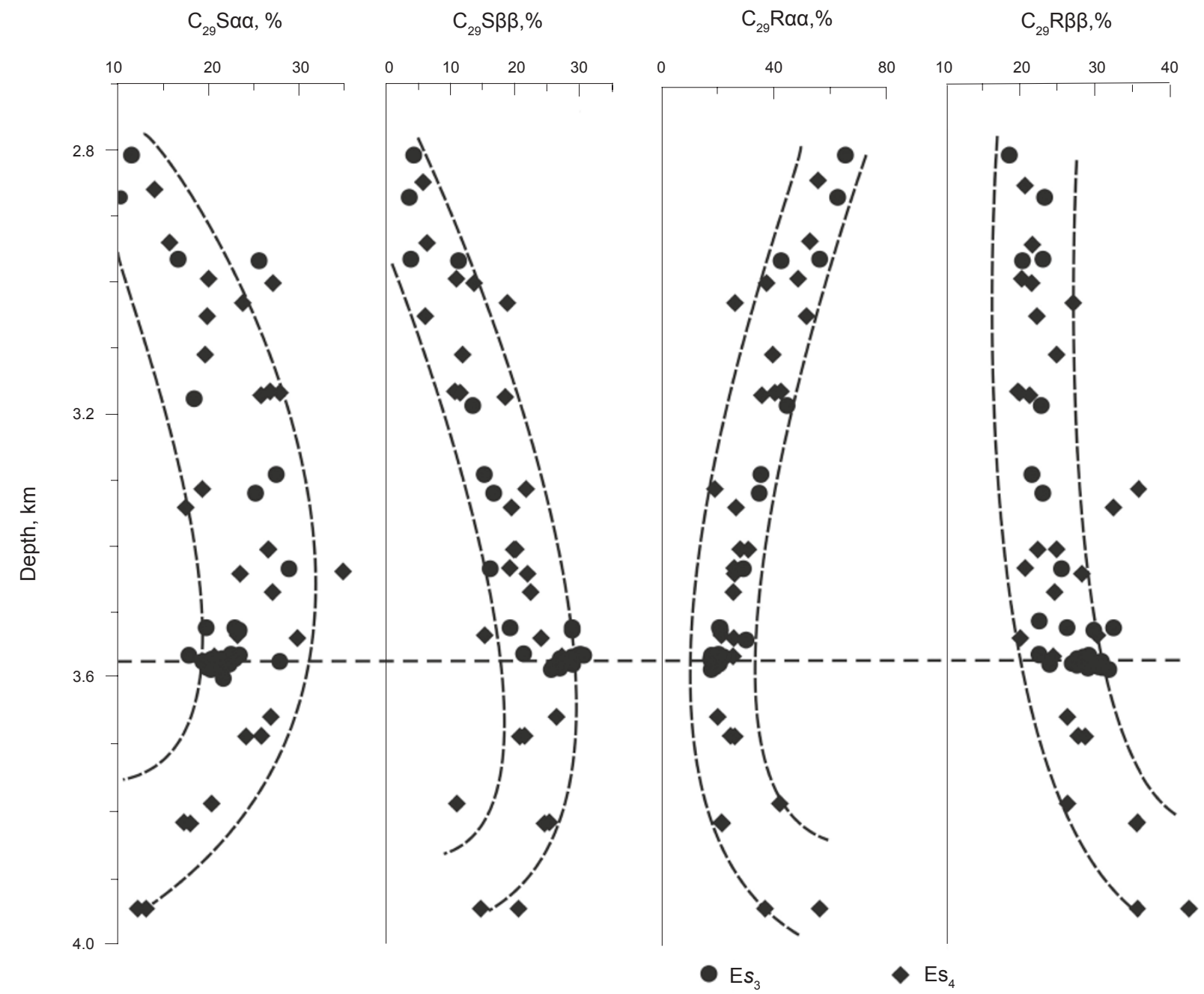

Fig. 2 Distribution of biomarker isomers related to $\mathrm{C}_{29}$ 24-ethyl sterane in Member 3 and Member 4 profile of the Shahejie Formation in the Dongying Sag. The relative contents of $\mathrm{S} \alpha \alpha, \mathrm{S} \beta \beta, \mathrm{R} \alpha \alpha$ and $\mathrm{R} \beta \beta$ is the percentage of total $\mathrm{C}_{29}$ 24-ethyl sterane 


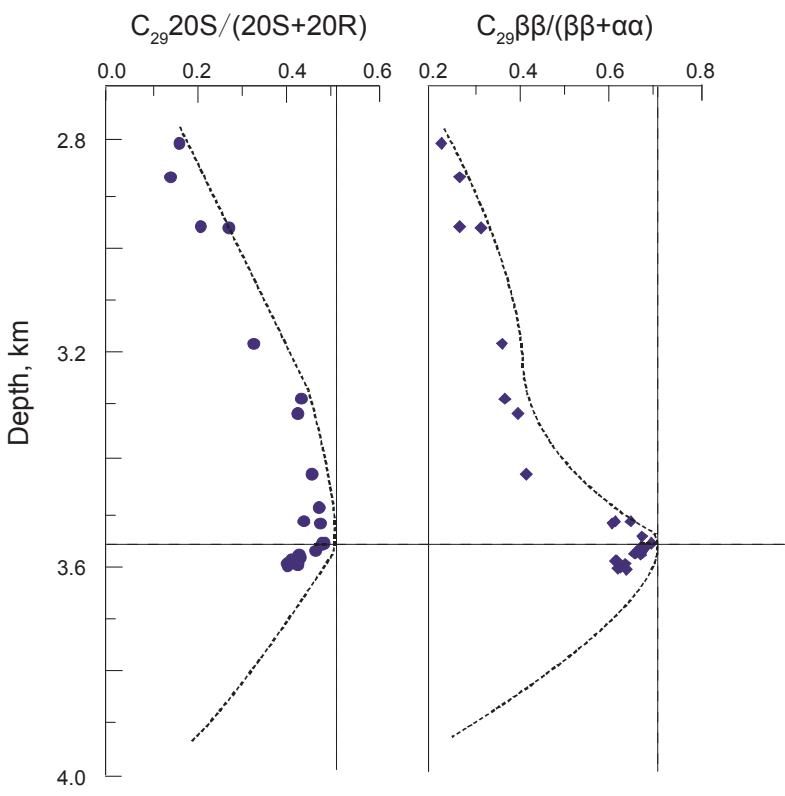

$\mathrm{a}\left(\mathrm{Es} s_{3}\right)$

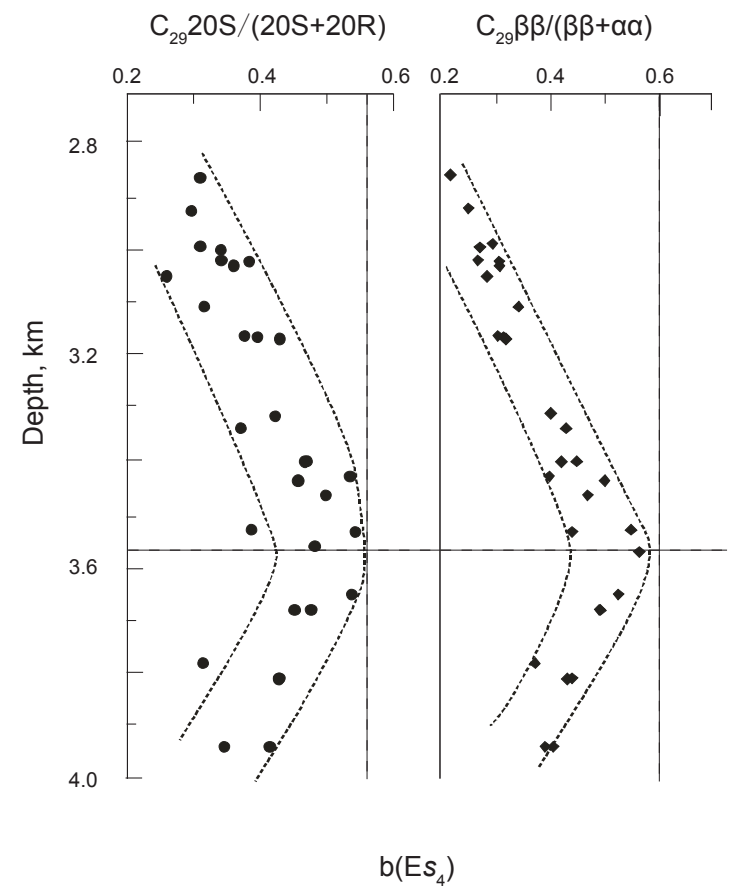

Fig. 3 Distribution of the parameters $C_{29} \beta \beta /(\beta \beta+\alpha \alpha)$ and $C_{29} 20 S /(20 S+20 R)$ in profiles from Member 3 and Member 4 of the Shahejie Formation in the Dongying Sag

(1986). They proposed that isomerization at C-20 of $5 \alpha, 14 a$, $17 \mathrm{a}(\mathrm{H})-\mathrm{C}_{29}$ cholestanes causes $\mathrm{C}_{29} 20 \mathrm{~S} /(20 \mathrm{~S}+20 \mathrm{R})$ to increase from 0 to around 0.5 , and isomerization at $\mathrm{C}-14$ and $\mathrm{C}-17$ of $\mathrm{C}_{29} 20 \mathrm{~S}$ and $20 \mathrm{R}$ regular cholestanes causes an increase in the $\mathrm{C}_{29} \beta \beta /(\beta \beta+\alpha \alpha)$ ratio from around zero to around 0.7 , with increasing thermal maturity. They obtained equilibrium values of $\mathrm{C}_{29} 20 \mathrm{~S} /(20 \mathrm{~S}+20 \mathrm{R})$ and $\mathrm{C}_{29} \beta \beta /(\beta \beta+\alpha \alpha)$ of $0.52-0.55$ and $0.61-0.71$, respectively.

The distribution and evolution process of the molecular parameters $\mathrm{C}_{29} \beta \beta /(\beta \beta+\alpha \alpha), \mathrm{C}_{29} 20 \mathrm{~S} /(20 \mathrm{~S}+20 \mathrm{R})$ and relative isomers from $2.8 \mathrm{~km}$ to $3.57 \mathrm{~km}$ are controlled by thermal maturation. In this interval depth, with increasing thermal maturation, the relative content of $S \alpha \alpha$ and $S \beta \beta$ in $C_{29}$ 24-ethyl cholestanes increases, the relative content of R $\alpha \alpha$ and $\mathrm{R} \beta \beta$ decreases, and $\mathrm{R} \alpha \alpha$ shows a stronger decline than $\mathrm{R} \beta \beta$. This result shows that between hydrocarbon generation and thermal equilibrium, the transformation of $20 \mathrm{R}$ is faster than that of 20S, including some transformation from $20 \mathrm{R}$ to $20 \mathrm{~S}$ (mainly $\mathrm{C}_{29} \mathrm{R} \alpha \alpha$ ), and the transformation of the $\alpha \alpha$ structure is faster than that of the $\beta \beta$ structure. The rate of transformation follows the order: $\mathrm{C}_{29} \mathrm{R} \alpha \alpha>\mathrm{C}_{29} \mathrm{R} \beta \beta>\mathrm{C}_{29} \mathrm{~S} \alpha \alpha>\mathrm{C}_{29} \mathrm{~S} \beta \beta$. The relative rates of both generation and degradation of the two isomers may control the $\mathrm{C}_{29} \beta \beta /(\beta \beta+\alpha \alpha)$ and $\mathrm{C}_{29} 20 \mathrm{~S} /$ $(20 \mathrm{~S}+20 \mathrm{R})$ ratios, consistent with the result by Farrimond et al (1998). The point is that the evolution of the molecular parameters $\mathrm{C}_{29} \beta \beta /(\beta \beta+\alpha \alpha)$ and $\mathrm{C}_{29} 20 \mathrm{~S} /(20 \mathrm{~S}+20 \mathrm{R})$ is mainly controlled by the different rate of their thermal degradation due to the difference in their thermal stability, and the different rate of thermal degradation results in the change of relative content of isomers. In this process, some transformations take place between isomers because of isomerization, but they are not the main controlling factor.

\subsection{Reversal of maturity parameters at $3.57-4.0 \mathrm{~km}$}

Reversal of molecular parameters at high maturities has been known for some time. The $\mathrm{C}_{29} 20 \mathrm{~S} /(20 \mathrm{~S}+20 \mathrm{R})$ and $C_{29} \beta \beta /(\beta \beta+\alpha \alpha)$ ratios are the most commonly reported biomarker maturity parameters related to this reversal. Lewan et al (1986) found that the $\mathrm{C}_{29} 20 \mathrm{~S} /(20 \mathrm{~S}+20 \mathrm{R})$ ratio increases with increasing temperatures up to $330{ }^{\circ} \mathrm{C}$ in hydro-pyrolysis experiments for samples of the Phosphoria Shale, and that the trend is then reversed after reaching a thermal equilibrium (at $0.55)$. In the hydrous pyrolysis experiments with immature Phosphoria Shale samples, which are rich in dolomite and phosphate, from the Santa Maria Basin, Peters et al (1990) found that after equilibrium $\left(330^{\circ} \mathrm{C}\right)$, the $\mathrm{C}_{29} \beta \beta /(\beta \beta+\alpha \alpha)$ and $\mathrm{C}_{29} 20 \mathrm{~S} /(20 \mathrm{~S}+20 \mathrm{R})$ ratios shows a reversal trend, which is consistent with the experimental results of Lewan (1986). But in the experiments with samples rich in clay minerals (Peters et al, 1990), the values of $C_{29} \beta \beta /(\beta \beta+\alpha \alpha)$ and $C_{29} 20 S /(20 S+20 R)$ ratios continue to increase without reversal occuring. This suggests that different mineral compositions are likely to be an important controlling factor for isomerization at low temperature; while at high temperature, differences in thermal stability between different isomers are the main controlling factor. In a pyrolysis of Jurassic black shales from the Cape Range 2 Well in the Carnarvon Basin, Strachan et al (1989) found that at $2,850 \mathrm{~m}$, the $\mathrm{C}_{29} 20 \mathrm{~S} /(20 \mathrm{~S}+20 \mathrm{R})$ ratio reaches an equilibrium value of 0.55 , but there is then a reversal trend. This phenomenon was suggested to be associated with the different cracking rate, as the thermal stability of the $20 \mathrm{~S}$ and $20 \mathrm{R}$ configuration is different. It may also be associated with high abundances of organic matter and low content of minerals, which contribute to the lag of cracking in the process. In the Pingluoba region of the Sichuan Basin, and 
Chande region of the Songliao Basin in China, the $R_{\mathrm{o}}$ of the source rocks is $>1.65 \%$, while the $\mathrm{C}_{29} \beta \beta /(\beta \beta+\alpha \alpha)$ and $\mathrm{C}_{29} 20 \mathrm{~S} /$ $(20 \mathrm{~S}+20 \mathrm{R})$ ratios show abnormal low values; these values suggests that they are resulted from the different cracking rates between different isomers (Chen, 1997).

Causes of the reversal in biomarkers ratios distribution are complex. But this study shows that minerals have a larger effect on the reversal than other factors. The reversal of the related biomarker parameters is accordence with a significant increase in the content of evaporitic rocks.
Regional geological data shows that at a shallower burial depth $(<3.5 \mathrm{~km})$, the main source rocks are calcareous shales and mudstone; at a deeper burial depth $(>3.5 \mathrm{~km})$, the content of evaporites (gypsum and halite) increases significantly, and the evaporites and mudstones formed into a single sedimentary system (i.e. co-sedimentary system), as shown in the Haoke-1 Well in Fig. 4. In the co-sedimentary system, the contents of elements such as calcium and sodium greatly increase, and the $\mathrm{Sr} / \mathrm{Ba}, \mathrm{Sr} / \mathrm{Ca}$ and $\mathrm{Fe} / \mathrm{Mn}$ ratios display significant high-value response (Fig. 4), indicating a typical

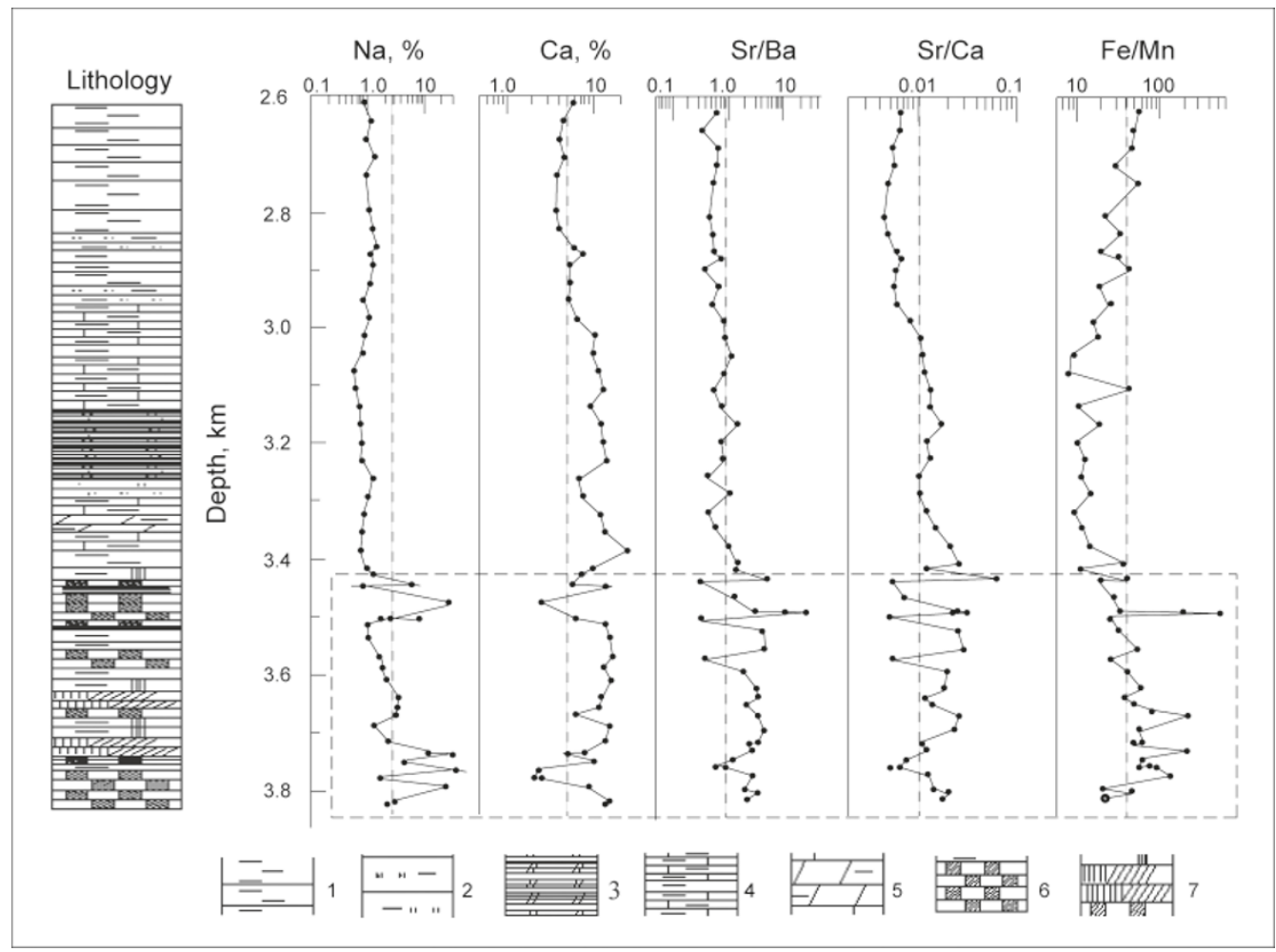

Fig. 4 Distribution of contents and ratios of mineral elements in the Paleogene system profile from Haoke-1 Well in the Dongying Sag 1. mudstone; 2. silty mudstone; 3. oil shale; 4. calcic mudstone; 5. argillaceous dolomite; 6. halite; 7. gypsum and halite

high-saline environment (Chen and zha, 2008). The deep $\mathrm{E} s_{3}$ can also be affected by the high salinity in $\mathrm{Es}_{4}$ through formation water migration along faults or other channels. Furthermore, the high response of gammacerane also shows a hypersaline depositional environment and the marked stratification in the saline water environment with a halocline (Peters and Moldowan, 1993; Sinninghe Damsté et al, 1995; Wang, 2002) (Fig. 5, Fig. 6). In Fig. 5 the long-chain homohopanes display the characteristics of $\mathrm{C}_{35}$ hopane $>\mathrm{C}_{34}$ hopane $>\mathrm{C}_{33}$ hopane, and this also reflects the characteristics of biomarkers in the depositional environment with high salinity (Seifert and Moldowan, 1979, 1981; Tissot and welte, 1984; zhu et al, 2004).

Among the 50 samples, 30 samples were tested by RockEval pyrolysis and chromatograph. Three data from Feng8 Well (3816.3 m, $3818 \mathrm{~m}, 3947 \mathrm{~m}$ ) show higher $\mathrm{Pr} / \mathrm{n}-\mathrm{C}_{17}$, $\mathrm{Ph} / \mathrm{n}-\mathrm{C}_{18}$ and lower $\mathrm{Pr} / \mathrm{Ph}$ values compared to the other data (Table 2). The distributions of pristine/phytane $(\mathrm{Pr} / \mathrm{Ph})$ and gammacerane $/ \mathrm{C}_{30} 17 \alpha$-Hopane are well differentiated by the two class of samples, and the samples from the evaporated system in the Member 4 show the dominance of phytane

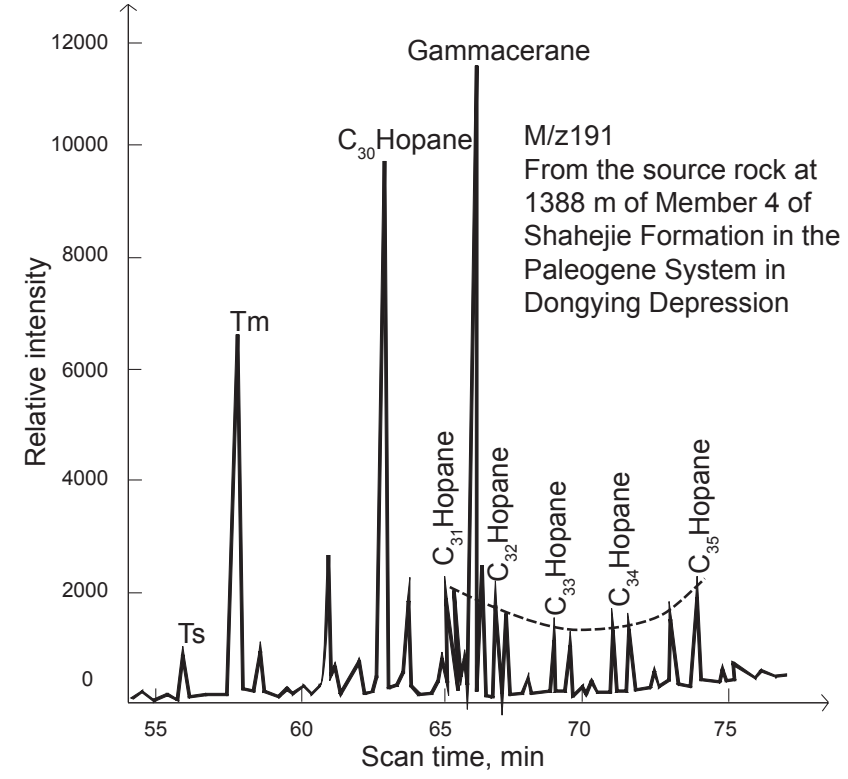

Fig. 5 Distribution of a typical response of gammacerane and the hopane series in the $\mathrm{m} / \mathrm{z} 191$ of the evaporite system in the Dongying Sag 


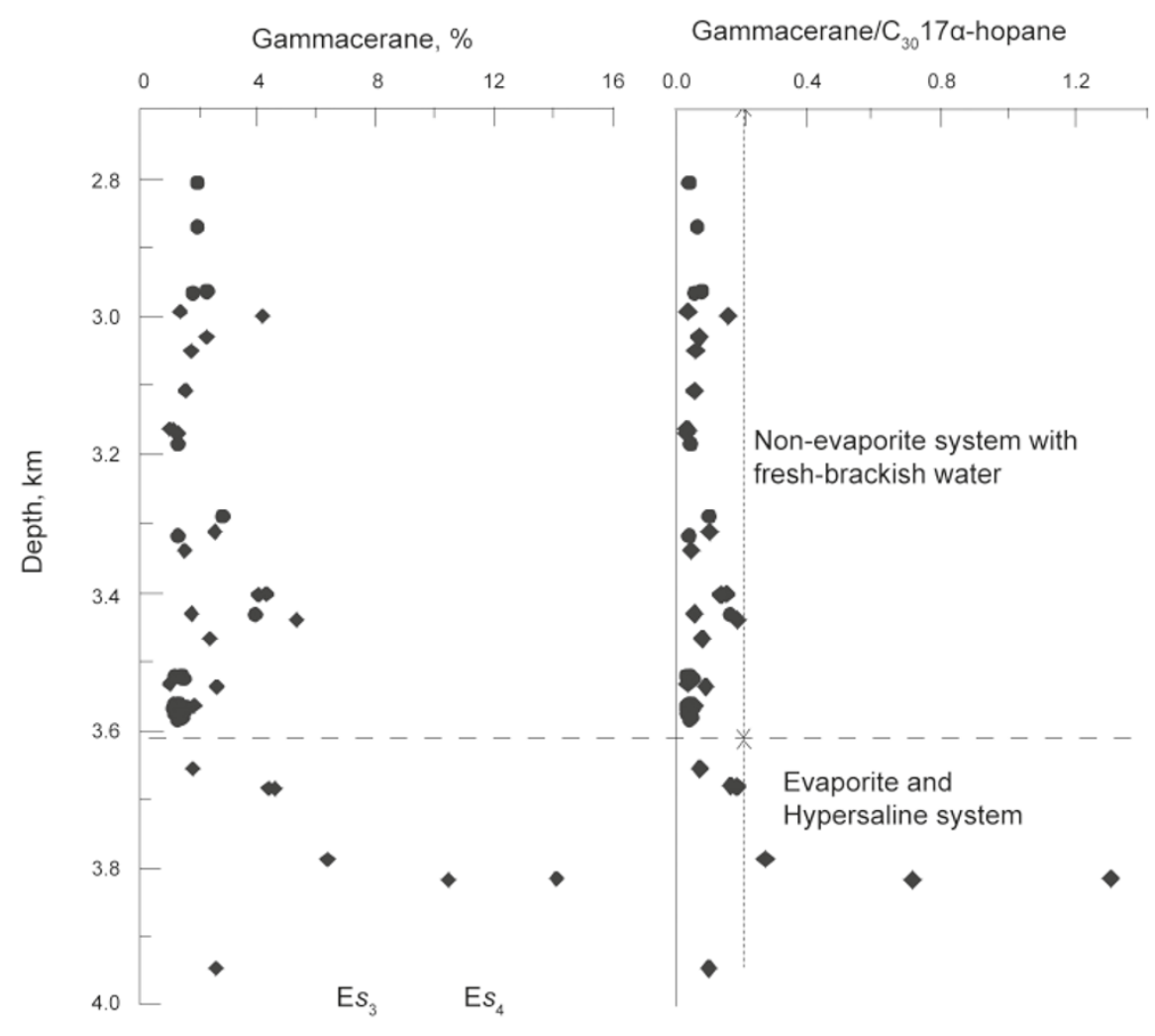

Fig. 6 High response of gammacerane and gammacerane/17 $\alpha$-hopane in the deep hypersaline source rocks of Paleogene System in the Dongying Sag

$(\mathrm{Pr} / \mathrm{Ph}<1.0)$ and high gammacerane response (gammacerane/ $\mathrm{C}_{30}$ Hopane $>0.065$ ) (Fig. 7). Such high gammacerane indices and low pristine/phytane of the samples from the evaporite system reflect increased water salinity during deposition. This result is in accordance with the understanding of ten Haven et al (1987) and Schwark et al (1998). ten Haven et al (1987)

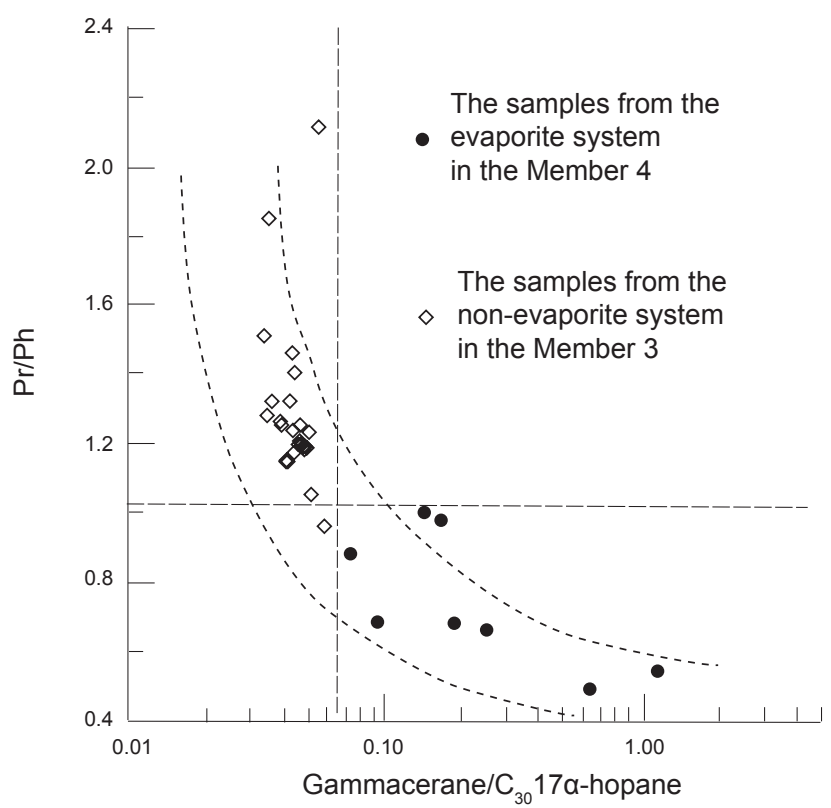

Fig. 7 Distribution of $\mathrm{Pr} / \mathrm{Ph}$ and $\gamma / \mathrm{C}_{30} \mathrm{H}$ of the source rocks from the evaporite system of Member 4 and non-evaporite system of Member 3 in Dongying depression. This data was from 32 samples that were analyzed with GC and GCMS recommended that low $\mathrm{Pr} / \mathrm{Ph}(<1)$ is typical of hypersaline environments, and the $\mathrm{Pr} / \mathrm{Ph}$ ratio has a relationship with the salinity that halophilic bacteria depend on. Likewise, Schwark et al (1998) noted a general decrease in $\mathrm{Pr} / \mathrm{Ph}$ during deposition of the Permian Kupferschiefer sequence in Germany, and they interpreted it as increasing paleosalinity. Although the validity of the $\mathrm{Pr} / \mathrm{Ph}$ ratio is limited in accurately describing the paleoenvironments, which are also related to other factors, including variable source rock inputs, different rates of early generation, variations at higher maturity and analytical uncertainty (Peters and Moldowan, 1993), the relationship between $\mathrm{Pr} / \mathrm{Ph}$ and gammacerane index reinforces the relationship of $\mathrm{Pr} / \mathrm{Ph}$ and salinity.

The statistical analysis of 30 samples on the relationship between commonly-used maturity indicators, vitrinite reflectance $\left(R_{\mathrm{o}}\right)$, and the $\mathrm{C}_{29} \beta \beta /(\beta \beta+\alpha \alpha)$ and $\mathrm{C}_{29} 20 \mathrm{~S} /$ $(20 \mathrm{~S}+20 \mathrm{R})$ ratios show positive correlations between them. However, the three samples $(3816.3 \mathrm{~m}, 3818 \mathrm{~m}, 3947 \mathrm{~m}$ of the Well Feng-8) from a hypersaline environment in $E s_{4}$ depart from the normal distribution trend, indicating that with increasing $R_{\mathrm{o}}$, the $\mathrm{C}_{29} \beta \beta /(\beta \beta+\alpha \alpha)$ of the three samples increases very little and even decreases in $C_{29} 20 \mathrm{~S} /(20 \mathrm{~S}+20 \mathrm{R})$ (Fig. 8), which implied that the biomarker maturity parameters $\mathrm{C}_{29} \beta \beta /(\beta \beta+\alpha \alpha)$ and $\mathrm{C}_{29} 20 \mathrm{~S} /(20 \mathrm{~S}+20 \mathrm{R})$ are more negatively affected by hypersaline environment than by $R_{\mathrm{o}}$.

In the $\mathrm{Es}_{4}$ hypersaline environment $(>3.5 \mathrm{~km})$, the relative contents of isomers $\mathrm{S} \alpha \alpha$ and $\mathrm{S} \beta \beta$ decrease, and the relative contents of isomers $R \alpha \alpha$ and $R \beta \beta$ increase with increasing burial depth. The relative contents of total $\beta \beta(S \beta \beta+R \beta \beta)$ and total S-type $(\mathrm{S} \alpha \alpha+\mathrm{S} \beta \beta)$ decrease with thermal evolution, and 
Table 2 The general geochemical properties of some samples

\begin{tabular}{|c|c|c|c|c|c|c|c|c|c|c|c|c|c|c|c|c|}
\hline Well & Strata & $\begin{array}{l}\text { Depth } \\
\mathrm{m}\end{array}$ & $R_{\mathrm{o}}$ & $T_{\max }$ & TOC & OEP & CPI & $\begin{array}{l}\mathrm{C}_{21}+\mathrm{C}_{22} / \\
\mathrm{C}_{28}+\mathrm{C}_{29}\end{array}$ & $\begin{array}{l}\Sigma \mathrm{C}_{21}{ }^{-} / \\
\Sigma \mathrm{C}_{22}{ }^{+}\end{array}$ & IH & $\begin{array}{c}\mathrm{Pr} / \\
\mathrm{n}-\mathrm{C}_{17}\end{array}$ & $\begin{array}{c}\mathrm{Ph} / \\
\mathrm{n}-\mathrm{C}_{18}\end{array}$ & $\mathrm{Pr} / \mathrm{Ph}$ & $\mathrm{R}_{30} / \mathrm{H}_{30}$ & $\begin{array}{c}\mathrm{C}_{29} \beta \beta / \\
(\beta \beta+\alpha \alpha)\end{array}$ & $\begin{array}{c}\mathrm{C}_{29} 20 \mathrm{~S} / \\
(20 \mathrm{~S}+20 \mathrm{R})\end{array}$ \\
\hline FS-1 & $\mathrm{E} s_{3}$ & 2870 & 0.49 & 436 & 1.21 & 1.55 & 1.69 & 1.34 & 0.94 & 382.4 & 0.9 & 1.27 & 0.96 & 0.070 & 0.27 & 0.14 \\
\hline Shi-121 & $\mathrm{E} s_{3}$ & 3289.6 & 0.6 & 443 & 0.96 & 1.34 & 1.29 & 1.19 & 0.49 & 93.5 & 1.16 & 0.52 & 2.13 & 0.105 & 0.37 & 0.43 \\
\hline Shi-121 & $\mathrm{E} s_{3}$ & 3318 & 0.6 & 439 & 0.76 & 1.27 & 1.37 & 2.21 & 1.01 & 173.5 & 0.49 & 0.39 & 1.25 & 0.046 & 0.40 & 0.42 \\
\hline Shi-121 & $\mathrm{E} s_{3}$ & 3521.8 & 0.64 & 441 & 0.88 & 1.17 & 1.24 & 1.7 & 0.77 & 236.4 & 0.63 & 0.46 & 1.4 & 0.049 & 0.65 & 0.43 \\
\hline Shi-121 & $\mathrm{Es}_{3}$ & 3561.9 & 0.66 & 443 & 2.76 & 1.09 & 1.13 & 2.44 & 0.89 & 272.9 & 0.29 & 0.21 & 1.24 & 0.050 & 0.62 & 0.47 \\
\hline Shi-121 & $\mathrm{E} s_{3}$ & 3563 & 0.66 & 443 & 2.82 & 1.1 & 1.14 & 2.43 & 0.91 & 349.0 & 0.29 & 0.2 & 1.26 & 0.044 & 0.62 & 0.48 \\
\hline Shi-121 & $\mathrm{E} s_{3}$ & 3563.5 & 0.66 & 442 & 1.29 & 1.17 & 1.21 & 2.56 & 0.96 & 215.8 & 0.48 & 0.36 & 1.32 & 0.041 & 0.69 & 0.43 \\
\hline Shi-121 & $\mathrm{E} s_{3}$ & 3565.9 & 0.7 & 440 & 0.58 & 1.14 & 1.2 & 1.86 & 0.87 & 239.8 & 0.63 & 0.49 & 1.25 & 0.052 & 0.59 & 0.47 \\
\hline Shi-121 & $\mathrm{E} s_{3}$ & 3568.5 & 0.72 & 444 & 1.32 & 1.13 & 1.2 & 1.66 & 0.84 & 440.9 & 0.59 & 0.38 & 1.51 & 0.037 & 0.64 & 0.43 \\
\hline Shi-121 & $\mathrm{E} s_{3}$ & 3569.25 & 0.7 & 443 & 1.63 & 1.14 & 1.17 & 2.16 & 0.92 & 417.4 & 0.43 & 0.37 & 1.05 & 0.058 & 0.67 & 0.44 \\
\hline Shi-121 & $\mathrm{E} s_{3}$ & 3572.8 & 0.68 & 442 & 1.59 & 1.14 & 1.19 & 2.14 & 0.97 & 305.4 & 0.44 & 0.3 & 1.46 & 0.048 & 0.68 & 0.42 \\
\hline Shi-121 & $\mathrm{E} s_{3}$ & 3575.8 & 0.7 & 446 & 0.92 & 1.13 & 1.23 & 1.63 & 0.92 & 217.2 & 0.71 & 0.4 & 1.85 & 0.040 & 0.63 & 0.43 \\
\hline Shi-121 & $\mathrm{E} s_{3}$ & 3577.2 & 0.72 & 442 & 1.71 & 1.15 & 1.2 & 1.95 & 0.92 & 288.6 & 0.49 & 0.35 & 1.32 & 0.047 & 0.63 & 0.46 \\
\hline Shi-121 & $\mathrm{E} s_{3}$ & 3578.5 & 0.7 & 441 & 1.39 & 1.1 & 1.15 & 1.7 & 0.87 & 342.3 & 0.45 & 0.37 & 1.17 & 0.050 & 0.65 & 0.43 \\
\hline Shi-121 & $\mathrm{E} s_{3}$ & 3580.8 & 0.68 & 446 & 2.17 & 1.07 & 1.11 & 1.66 & 0.87 & 302.5 & 0.32 & 0.27 & 1.2 & 0.052 & 0.66 & 0.41 \\
\hline Shi-121 & $\mathrm{E} s_{3}$ & 3582.1 & 0.68 & 434 & 2.43 & 1.06 & 1.1 & 1.64 & 0.82 & 192.4 & 0.32 & 0.27 & 1.19 & 0.054 & 0.67 & 0.41 \\
\hline Shi-121 & $\mathrm{E} s_{3}$ & 3582.7 & 0.7 & 443 & 2.13 & 1.06 & 1.09 & 1.77 & 0.87 & 275.4 & 0.31 & 0.26 & 1.2 & 0.053 & 0.66 & 0.43 \\
\hline Shi-121 & $\mathrm{Es}_{3}$ & 3585 & 0.66 & 442 & 2.57 & 1.07 & 1.1 & 1.76 & 0.83 & 302.9 & 0.33 & 0.28 & 1.15 & 0.047 & 0.67 & 0.41 \\
\hline Shi-126 & $\mathrm{E} s_{3}$ & 3521.9 & 0.62 & 446 & 1.87 & 1.12 & 1.2 & 2.44 & 1.47 & 301.8 & 0.46 & 0.4 & 1.28 & 0.039 & 0.61 & 0.37 \\
\hline Shi-126 & $\mathrm{E} s_{3}$ & 3525.6 & 0.63 & 446 & 3.02 & 1.09 & 1.1 & 1.63 & 0.79 & 271.6 & 0.4 & 0.32 & 1.23 & 0.057 & 0.61 & 0.47 \\
\hline Feng-8 & $\mathrm{E} s_{4}$ & 3050 & 0.57 & 439 & 1.87 & 1.15 & 1.25 & 1.52 & 1 & 385.9 & 0.59 & 0.72 & 0.95 & 0.065 & 0.28 & 0.26 \\
\hline Feng-8 & $\mathrm{E} s_{4}$ & 3164 & 0.52 & 441 & 1.99 & 1.15 & 1.22 & 1.49 & 0.87 & 401.4 & 0.5 & 0.44 & 1.2 & 0.038 & 0.30 & 0.38 \\
\hline Feng-8 & $\mathrm{E} s_{4}$ & 3166 & 0.58 & 446 & 2.17 & 1.23 & 1.32 & 2.32 & 1.04 & 543.2 & 0.5 & 0.45 & 1.21 & 0.044 & 0.32 & 0.39 \\
\hline Feng-8 & $\mathrm{E} s_{4}$ & 3403 & 0.65 & 442 & 4.42 & 1.04 & 1.1 & 1.1 & 0.71 & 126.5 & 0.62 & 0.93 & 0.71 & 0.157 & 0.45 & 0.47 \\
\hline Feng-8 & $\mathrm{E} s_{4}$ & 3816.3 & 0.86 & 427 & 1.23 & 1.02 & 1.05 & 2.29 & 1.12 & 397.2 & 0.93 & 1.75 & 0.54 & 1.300 & 0.61 & 0.43 \\
\hline Feng-8 & $\mathrm{E} s_{4}$ & 3818 & 0.85 & 424 & 1.13 & 1 & 1.04 & 2.03 & 0.82 & 402.3 & 0.96 & 1.78 & 0.49 & 0.712 & 0.60 & 0.43 \\
\hline Feng-8 & $\mathrm{E} s_{4}$ & 3947 & 0.92 & 419 & 0.49 & 1.09 & 1.09 & 1.62 & 1.35 & 302.7 & 1.16 & 1.46 & 0.68 & 0.105 & 0.62 & 0.41 \\
\hline FS-1 & $\mathrm{E} s_{4}$ & 3440 & 0.56 & 443 & 1.66 & 1.1 & 1.17 & 1.45 & 0.73 & 53.9 & 0.52 & 0.77 & 0.71 & 0.190 & 0.50 & 0.46 \\
\hline FS-1 & $\mathrm{E} s_{4}$ & 3685.6 & 0.66 & 446 & 2.29 & 1.03 & 1.05 & 1.68 & 1.15 & 405.5 & 0.35 & 0.35 & 1.07 & 0.173 & 0.49 & 0.47 \\
\hline FS-1 & $\mathrm{E} s_{4}$ & 3686.3 & 0.7 & 449 & 1.99 & 1.01 & 1.05 & 1.41 & 0.9 & 377.0 & 0.33 & 0.34 & 1.03 & 0.180 & 0.50 & 0.45 \\
\hline
\end{tabular}

the relative contents of total $\alpha \alpha(\mathrm{S} \alpha \alpha+\mathrm{R} \alpha \alpha)$ and total R-type $(\mathrm{R} \alpha \alpha+\mathrm{R} \beta \beta)$ decrease. This indicates that the transformation of $20 \mathrm{R}$ and $\alpha \alpha$ structure was retarded or inhibited compared to that of $20 \mathrm{~S}$ and $\beta \beta$ structure.

The negative reversal of $\mathrm{C}_{29}$ 24-ethyl cholestane isomers and the $\mathrm{C}_{29} \beta \beta /(\beta \beta+\alpha \alpha)$ and $\mathrm{C}_{29} 20 \mathrm{~S} /(20 \mathrm{~S}+20 \mathrm{R})$ ratios in hypersaline environments reflects the negative effect of gypsum-halite on isomerization and thermal evolution of organic matter.

This negative effect of gypsum-halite on the biomarker maturity parameters is supported by the distributions of maturity-related biomarker parameters $\mathrm{Ts} / \mathrm{Tm}$ and $\mathrm{Ts} /$ (Ts $+\mathrm{Tm}$ ), which display negative reversal similar to $\mathrm{C}_{29} \beta \beta /$ $(\beta \beta+\alpha \alpha)$ and $\mathrm{C}_{29} 20 \mathrm{~S} /(20 \mathrm{~S}+20 \mathrm{R})$ (Fig. 9). The reversal of the $\mathrm{C}_{29} \beta \beta /(\beta \beta+\alpha \alpha)$ and $\mathrm{C}_{29} 20 \mathrm{~S} /(20 \mathrm{~S}+20 \mathrm{R})$ ratios is associated with specific lithologies such as carbonates or evaporitic rocks other than the result of isomerisation, a process commonly interpreted as the controlling factor for the relative contents of biomarkers (and thus molecular maturity parameters). Also, such inhibition or retardation by carbonate minerals is found in some evaporite systems, and supported by some immature to low-matured oils discovered in high carbonate evaporite 

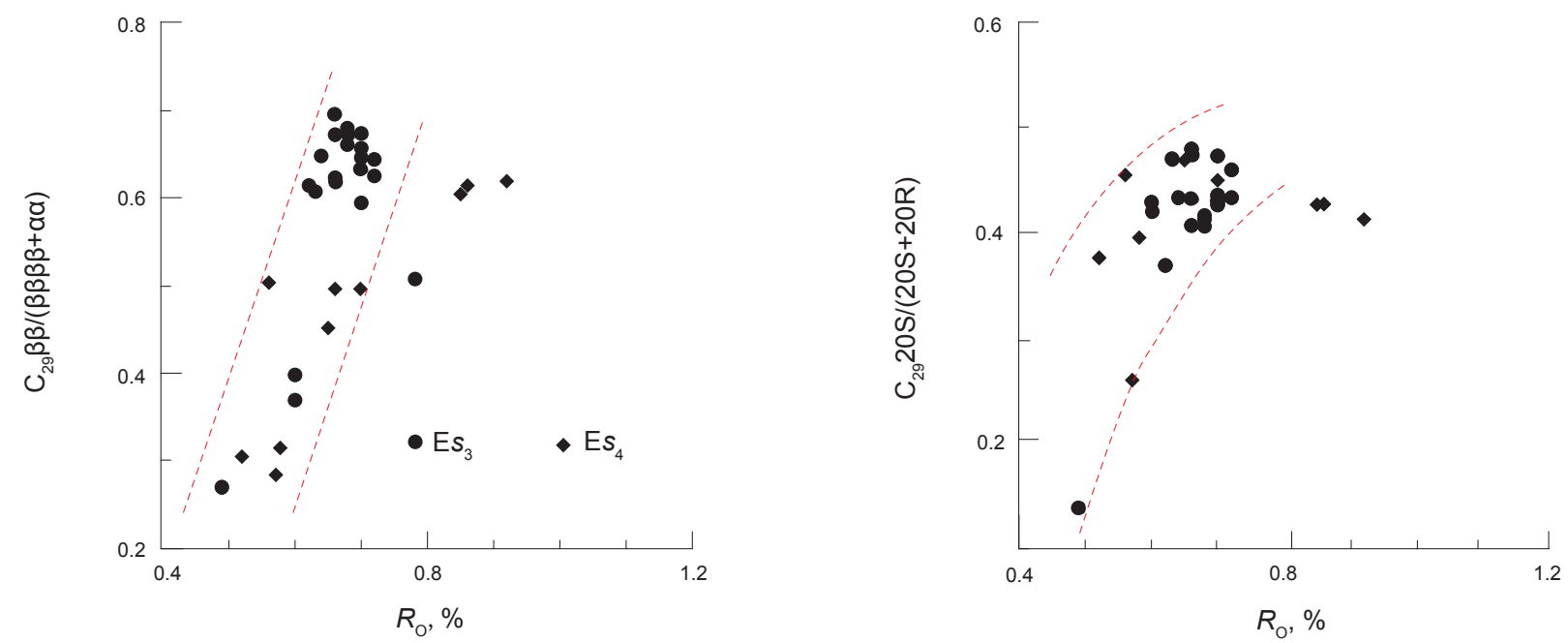

Fig. 8 Relationship between $\mathrm{C}_{29} \beta \beta /(\beta \beta+\alpha \alpha), \mathrm{C}_{29} 20 \mathrm{~S} /(20 \mathrm{~S}+20 \mathrm{R})$ and $R_{\mathrm{o}}$ for the 32 samples from the Paleogene system in the Dongying Sag. The three abnormal data are from the hypersaline source rocks from Member 4 ( 3816.3 m, 3818 m, 3947 m in the Feng-8 well)

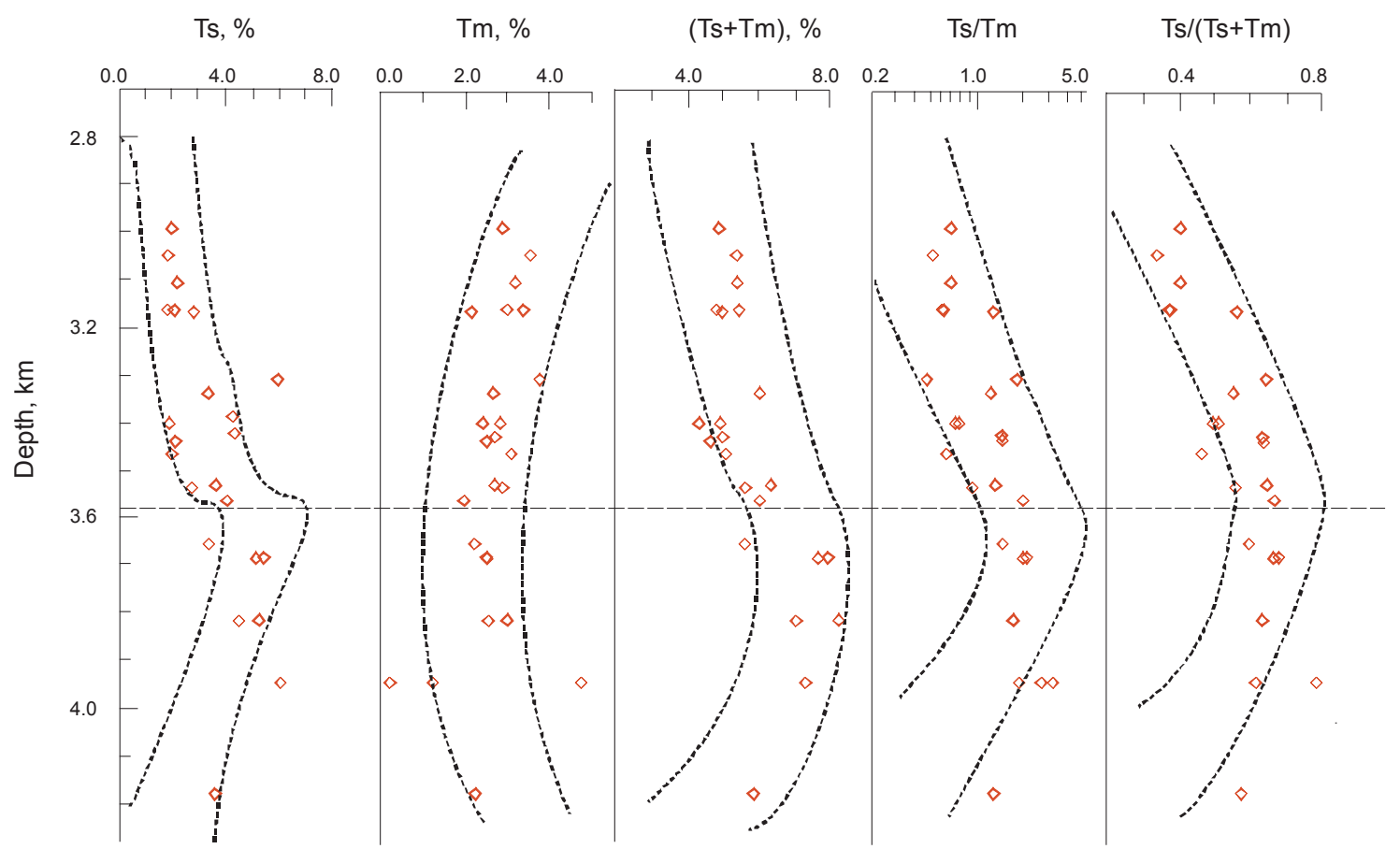

Fig. 9 Distribution of the parameters $\mathrm{Ts} / \mathrm{Tm}$ and $\mathrm{Ts} /(\mathrm{Ts}+\mathrm{Tm})$ in profile from the Member 4 of Shahejie Formation in the Paleogene system in the Dongying sag

system. The retarding effect is proposed to mainly due to the absence of catalysis of clay minerals (Tuo et al, 1994), for the calcites in the gypsum-halite play little or no role in the transformation of kerogen. The low content of clay and sometimes even deficiency in gypsum-halite rocks may result in the retardation of thermal evolution in evaporite systems. This is supported by thermal simulation experiments, which shows the effect of different substrates on the hydrocarbon generation process. Carbonate rocks play an anti-catalytic role in hydrocarbon generation from kerogen, more evident as the temperature increases (Zhao et al, 2005). Such negative effect of carbonate minerals even occurs in the formation of diamondoids. Wei et al (2006) suggest that clay minerals have a significant catalysis effect on the formation of diamondoids, and may catalyze the diamondoid synthesis via carbonium ion mechanisms resulting from Lewis acid sites available on their surface; In contrast, $\mathrm{CaCO}_{3}$ has an inhibitary effect on the generation of diamondoids, as well as on diamondoid maturity parameters such as MAI and MDI. This inhibitary effect may be related to the mode of organic matter present in carbonate minerals, since in evaporite systems, the organic matter is mainly present within cryptocrystalline or finegrained carbonate minerals and may not be easily released as a result (Xie et al, 2000). 
The thermal retardation in the evaporite system is not only reflected by biomarker parameters but also displayed in the distribution of conventional thermal indicators including vitrinite reflectance $\left(R_{\mathrm{o}}\right)$ and pyrolysis peak temperature $\left(T_{\max }\right)$ (Fig. 10), which shows a similar negative reversal in evaporite rocks. But some differences are also apparent. For the $R_{\mathrm{o}}$ and $T_{\max }$ data, distinct negative anomalies begin to appear at the depth of around $2400 \mathrm{~m}$, which corresponds to the overpressure of this area. Around $3400 \mathrm{~m}, R_{\mathrm{o}}$ and $T_{\max }$ values show a stronger negative departure in their distribution. Such results indicate that two types of inhibition or retardation act on $R_{\mathrm{o}}$ and $T_{\max }$. The overpressure in the Dongying Sag is distributed in mudstones of the middle and lower parts of $\mathrm{Es}_{3}$ and gypsum-salt layer of $\mathrm{Es}_{4}$ (Chen and Zha, 2008). The negative departure of $R_{\mathrm{o}}$ and $T_{\max }$ in the overpressured interval (high overpressure, the pressure coefficient reaches 1.8) from 2,400 $\mathrm{m}$ to $3,400 \mathrm{~m}$ suggests the inhibition of thermal evolution in response to overpressure. The stronger decline of $R_{\mathrm{o}}$ and $T_{\max }$ in the hypersaline interval from $3,400 \mathrm{~m}$ to $4,000 \mathrm{~m}$ indicates similar retardation due to the presence of carbonate minerals, as with the related biomarker maturity ratios.

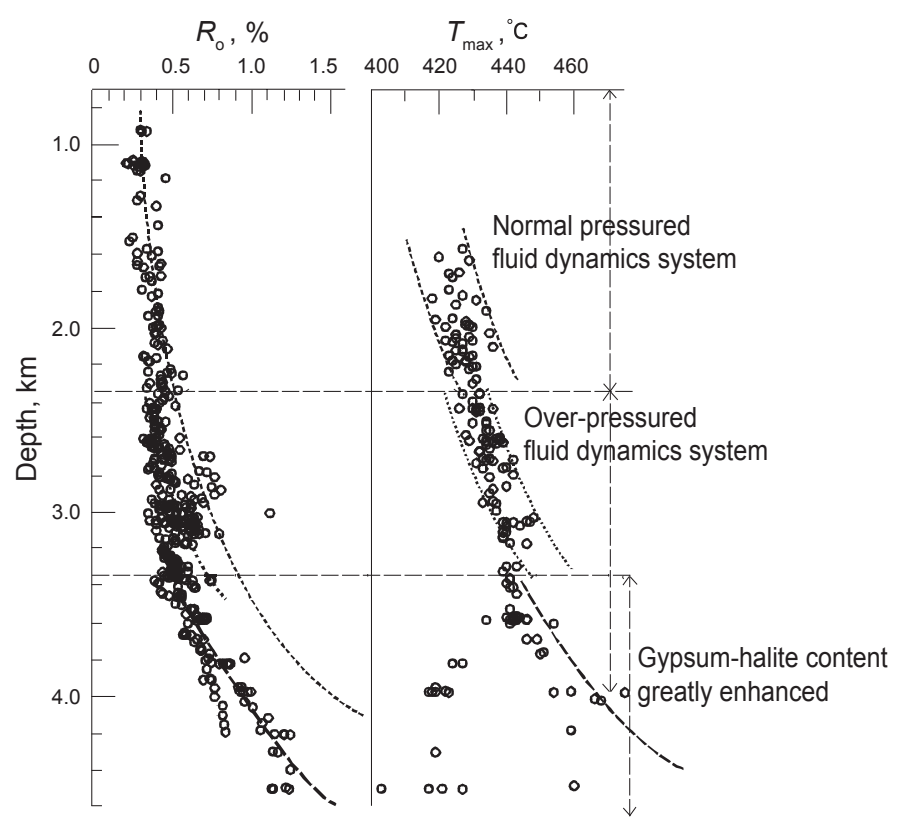

Fig. 10 Distribution of $R_{0}$ and $T_{\max }$ in profile in the Paleogene system of the Dongying Sag

\section{Conclusions}

1) Progressive changes in molecular maturity ratios are associated with major thermal evolutions of the biomarkers concerned. Increase in the ratios $\mathrm{C}_{29} \beta \beta /(\beta \beta+\alpha \alpha)$ and $\mathrm{C}_{29} 20 \mathrm{~S} /$ $(20 \mathrm{~S}+20 \mathrm{R})$ result from differences in the relative rates of generation and thermal degradation of these isomers. Transformation of the 20R isomers occurs more rapidly than $20 \mathrm{~S}$ isomer, including some transformation from $20 \mathrm{R}$ to $20 \mathrm{~S}$. $\alpha \alpha$ type $\mathrm{C}_{29} 24$-ethyl cholestanes degrade more rapidly than $\beta \beta$ type $\mathrm{C}_{29} 24$-ethyl cholestanes.

2) Below $3.5 \mathrm{~km}$ of the Paleogene system in Dongying sag in which evaporitic rocks deposited was a hyper-saline environment generally. In this environment high responses of $\mathrm{Sr} / \mathrm{Ba}, \mathrm{Sr} / \mathrm{Ca}, \mathrm{Fe} / \mathrm{Mn}, \mathrm{Pr} / \mathrm{n}-\mathrm{C}_{17}, \mathrm{Ph} / \mathrm{n}-\mathrm{C}_{18}$, gammacerane and low response of $\mathrm{Pr} / \mathrm{Ph}$ were observed.

3) The reversal of the molecular maturity ratios $\mathrm{C}_{29} \beta \beta /$ $(\beta \beta+\alpha \alpha), \mathrm{C}_{29} 20 \mathrm{~S} /(20 \mathrm{~S}+20 \mathrm{R}), \mathrm{Ts} /(\mathrm{Ts}+\mathrm{Tm})$ demonstrated the negative effects of gypsum-halite on isomerization of biomarkers isomers and organic matter thermal evolution.

\section{Acknowledgements}

This study was supported by the National Natural Science Foundation of China (40802026) and "the Fundamental Research Funds for the Central Universities". We acknowledge collaboration with and enthusiastic support from Shenli Oilfield (CPCC), and the assistance from Christopher Tiratsoo in having revised the paper with the English language presentation. We also thank the helpful reviewers and editor Yang Lei who gave valuable amendments for the manuscript.

\section{References}

Chen S J. The reversal of maturation parameters relative to $\mathrm{C}_{29}$ sterane. Natural Gas Geoscience. 1997. 8: 28-30 (in Chinese)

Chen Z H and Zha M. Sedimentary characteristics of source rocks in fluctuation from facies. Journal of Lake Science. 2006. 18: 19-25 (in Chinese)

Chen Z H and Zha M. Correlation between inorganic elements and abnormal vitrinite reflectance in the lacustrine source rocks: Taking Niu-38 Well in Dongying Depression as an example. Geochimica. 2007. 36: 275-278 (in Chinese)

Chen $\mathrm{Z} \mathrm{H}$ and Zha M. Mechanism of overpressured fluid compartment and its controlling on hydrocarbon migration and accumulation in faulted lacustrine basin: A case study from the Dongying Sag, Bohai Bay Basin. Chinese Journal of Geology. 2008. 43: 50-64 (in Chinese)

Chen Z H, Zha M and Jin Q. An investigation on generation and expulsion of hydrocarbon from source rocks of the Shahejie Formation in Well Niu-38, Dongying depression. Chinese Journal of Geology. 2004. 39: 356-366 (in Chinese)

Chen Z H, Zha M and Jin Q. Determining the hydrocarbon expulsion threshold of source rock of Well Niu-38. Natural Gas Industry. 2005. 25: 6-10 (in Chinese)

Chen Z H, Zha M and Jin Q. Mineral elemental response to the evolution of terrestrial faulted-lake basin. Acta Sedementilogica Sinica. 2008. 26: 36-43 (in Chinese)

Chen Z H, Zha M and Jin Q. Response of mineral elements, carbon isotope and hydrocarbon in typical sedimentary system of evaporate and mudstone: a case study of the Dongying Depression, Bohai Bay Basin. Acta Geologica Sinica. 2009. 83: 435-444 (in Chinese)

Dzou L I P, Noble R A. and Senftle J T. Maturation effects on absolute biomarker concentration in a suite of coals and associated vitrinite concentrates. Organic Geochemistry. 1995. 23: 681-697

Farrimond P, Taylor A and Telnæs N. Biomarker maturity parameters: the role of generation and thermal degradation. Org. Geochem. 1998. 29: 1181-1197

Lewan M D, Bjorøy M and Dolcater D L. Effects of thermal maturation on steroid hydrocarbons as determined by hydrous pyrolysis of Phosphoria Retort Shale. Geochimica et Cosmochimica Acta. 1986. 50: 1977-1987

Lewis C A. The kinetics of biomarker reactions: implications for the assessment of the thermal maturity of organic matter in sedimentary 
basins. In: Organic Geochemistry: Principles and Application (Eds. M. H. Engel and S. A. Macko). 1993. 491-510. New York: Plenum Press

Mackenzie A S. and Mckenzie D. Isomerization and aromatization of hydrocarbons in sedimentary basins formed by extension. Geology Magazine. 1983. 120: 417-470

Mackenzie A S, Patience R L, Maxwell J R, et al. Molecular parameters of maturation in the Toarcian shales, Paris Basin, France: Changes in the configuration of acyclic isoprenoid alkanes, steranes and triterpanes. Geochimica et Cosmochimica Acta. 1980. 44: 709-1721

Peters K E and Moldowan J M. The biomarker Guide: Interpreting Molecular Fossils in Petroleum and Ancient Sediments. New Jersey: Prentice Hall. 1993. 1-88

Peters K E, Moldowan, J M and Sundararaman P. Effects of hydrous pyrolysis on biomarker thermal maturity parameters: Monterey phosphatic and siliceous members. Organic Geochemistry. 1990. 15: 249-265

Requejo A G. Maturation of petroleum source rocks: II. Quantitative changes in extractable hydrocarbon content and composition associated with hydrocarbon generation. Organic Geochemistry. 1994. 21: 91-105

Rullkötter J and Marzi R. Natural and artificial maturation of biological markers in a Toarcian shale from northern Germany. Organic Geochemistry. 1988. 13: 639-645

Schwark L, Vliex M and Schaeffer P. Geochemical characterization of Malm Zeta laminated carbonates from the Franconian Alb, SWGermany. Organic Geochemistry. 1998. 29: 1921-1952.

Seifert W K and Moldowan J M. Use of biological markers in petroleum exploration. In: Methods in Geochemistry and Geophysics, 24 (Ed., R.B. Johns), Amsterdam. 1986. 261-290

Seifert W K and Moldowan J M. Paleoreconstrucation by biological markers. Geohimica et Coschimica Acta. 1981. 45: 783-794

Seifert W K and Moldowan J M. The effect of biodegradation on steranes and terpanes in crude oils. Geochimica et Coschimica Acta. 1979. 43: 111-126

Sinninghe Damsté, J S, Kening F, Koopmans. M P, et al. Evidence for gammacerane as an indicator of water-column stratification. Geochimica et Cosmochimica Acta. 1995. 59: 1895-1900
Strachan M G, Alexander R, Subroto E A, et al. Constraints upon the use of 24-ethylcholestane diastereomer ratios as indicators of the maturity of petroleum. Organic Geochemistry. 1989. 14: 423-432

ten Haven H L, de Leeuw J W, Peakman T M, et al. Anomalies in steroid and hopanoid maturity indices. Geochimica et Cosmochimica Acta. 1986. 50: 853-855

ten Haven H L, de Leeuw J W, RullkÖtter J, et al. Restricted utility of the prestane/phystane ratio as a palaeoenvironment indicator. Nature. 1987. 330: 641-643

Tissot B P and Welte D H. Petroleum Formation and Occurrence. Berlin, Heidelberg, NewYork, Tokyo: Spinger-Verlag. 1984. 59-62

Tuo J C, Huang X Z and Ma W Y. The Laging phenomenon of the petroleum generation in carbonate rocks. Petroleum Exploration and Development. 1994. 21: 1-5 (in Chinese)

Wang G L, Wang T G, Zhang L Y, et al. Anomalies of molecular indicators in Jiyang Eogene source rocks. Geochimica. 2006. 35: 560-566 (in Chinese)

Wang T G. A contribution to some sedimentary environmental biomarkers in crude oils and source rocks in China (in Chinese with English abstract): Geological Review. 2002. 48: 256-262

Wei Z B, Moldowan J M. and Paytan A. Diamondoids and molecular biomarkers generated from modern sediments in the absence and presence of minerals during hydrous pyrolysis. Organic Geochemistry. 2006. 37: 891-911

Xie Q L, Zhou Z Y and Lu M Y. Organic matter enclosed in carbonate minerals - a kind of important hydrocarbon producing matter. Acta Mineralogica Sinica. 2000. 20: 59-62 (in Chinese)

Zhao G Y, Li S Y and Liu L F. A study on characteristics and kinetics of catalytic degradation from kerogen in carbonate rocks. Chinese Journal of Geology. 2005. 40: 47-54 (in Chinese)

Zhu G Y, Jin Q, Dai J X, et al. Investigation on the salt lake source rocks for middle Shasi Column of Dongying Depression. Geological Journal of China Universities. 2004. 10: 257-266 (in Chinese)

Zhu G Y, Jin Q, Zhou J L, et al. Study on the infilling patterns of lacustrine basins in the Dongying Depression. Petroleum Geology and Experiment. 2003. 25: 143-148 (in Chinese)

(Edited by Zhu Xiuqin) 